\title{
Citizen Action for the Conservation of the Indiana Dunes National Lakeshore in Northwest Indiana
}

\author{
Stephanie Smith*, Steve Mark \\ Psychology Department, Indiana University Northwest, USA
}

Copyright $\bigcirc 2017$ by authors, all rights reserved. Authors agree that this article remains permanently open access under the terms of the Creative Commons Attribution License 4.0 International License

\begin{abstract}
The present article discusses citizen action strategies employed to preserve the Indiana Dunes National Lakeshore in the United States. Ecological pioneers Henry Chandler Cowles and Victor Shelford deemed this region to be of scientific importance, and the region played a role in the formation of the Ecological Society of America and The Nature Conservancy. Citizen action strategies included creating grassroots nonpartisan voluntary organizations, soliciting signatures on petitions, organizing letter-writing campaigns, soliciting media coverage, legal action, and persuading politicians to support preservation efforts. The struggle between heavy industry, residents, and conservationists resulted in the eventual parceling of the Northwest Indiana shoreline between steel mills, public lands, and residential areas. In one of the longest journeys to
\end{abstract}

the passage of a national park bill in the history of the United States, the Indiana Dunes National Lakeshore was established by an act of Congress in 1966. Several tracts of land have been added to it, and today the Indiana National Lakeshore consists of 15,000 non-contiguous acres along 15 miles of the south shore of Lake Michigan, with almost two million annual visitors.

Keywords Indiana Dunes National Lakeshore, Citizen Action Conservation, Indiana Dunes, Citizen Driven Environmental Action, The Nature Conservancy, Ecological Society of America, Henry Chandler Cowles, Victor Shelford

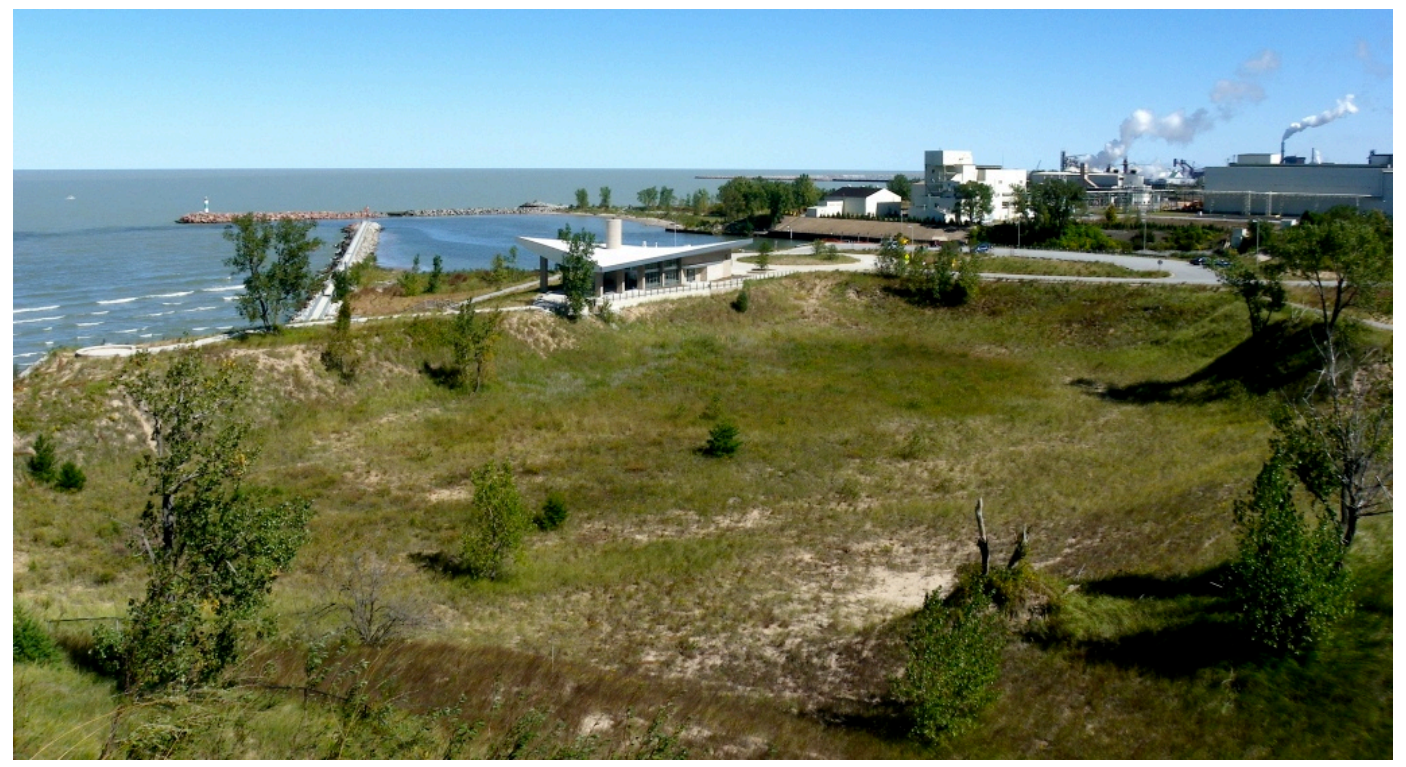

Photo credit: Frank Bellarmino

Picture 1. Indiana Dunes National Lakeshore and Steel Mill

......Mr. Humphrey (president of National Steel) has said that he prefers jobs to picnics. We ask, why is it not possible to have jobs and picnics?......[1] 


\section{Introduction}

In the 1950s the south shoreline of Lake Michigan of the United States became the focal point of a dispute between the industrial and economic interests of Northwest Indiana and local residents fighting over the preservation of the natural areas of the Indiana Dunes [2]. The region in dispute was identified by members of the 1913 International Phytogeographical Excursion and University of Chicago researchers Henry Chandler Cowles and Victor Shelford to be of scientific value [3]. This region is historically significant in the formation of the Ecological Society of America and The Nature Conservancy [3]. Our article describes the strategies used by citizen action groups who fought for conservation of these habitats and ecosystems. Some of these strategies involved soliciting signatures on petitions and organizing letter writing campaigns. Others included legal action, organizing citizen action groups, and garnering the support of a U.S. Senator. This case study provides useful information for communities around the world struggling for a balance between the interests of heavy industry, residents, and conservationists.

The south shore of Lake Michigan in Northwest Indiana today, more than fifty years after this dispute is a mosaic of industry, residential areas [4], and protected public lands. ArcelorMittal owns the former Bethlehem steel mill which was at the center of the dispute over protecting the natural areas of the Indiana Dunes. Currently, this mill is one of ArcelorMittal's largest facilities in the U.S, producing almost five million tons of raw steel annually. It is the only steel-making facility in the United States that is bordered on two sides by a national park.

\section{Materials and Methods}

The present article presents a case study of citizen action strategies to preserve the Indiana Dunes National Lakeshore in the United States spanning a time frame of decades that came to a successful resolution in the 1960s. The article presents an investigation and analysis of original published sources involving books, historical accounts, and newspaper articles, among other archival sources.

\section{Results and Discussion}

\subsection{Proposals for a Deep-Water Port along the South Shoreline of Lake Michigan}

In the early 1950s, there was considerable interest in establishing a deep water port on the South Shore of Lake Michigan. The state of Indiana was the only state in the Great Lakes region that did not have a deep water public port. The site of the proposed port was an area known as Burns Ditch, a small drainage ditch built in the early 1900s between the residential communities of Ogden Dunes and Dune Acres [5]. However, this land was located in the central area of a five-mile stretch of the Indiana Dunes, one of the last remnants of sand dunes, forests, marshes, and prairie plants on the south shore of Lake Michigan. Approximately 2000 acres of the Indiana Dunes east of Burns Ditch had been protected in 1925 with the establishment of the Indiana Dunes State Park [6]. But there was no protection for the central area of the Indiana Dunes, the site of the proposed Burns Harbor Waterway. This area was deemed of scientific importance by ecological pioneers Henry Chandler Cowles and Victor Shelford [3].

Along the Indiana shoreline of Lake Michigan approximately 17 miles had already been taken over by industry in the 1950s, with only approximately 8 miles left for public use [7]. The area immediately adjacent to Burns Ditch was owned by Midwest Steel, and the site of the proposed port was a mile east on land owned by Bethlehem Steel. It was hoped that a deep water port would bring in a new era of prosperity for the region. Federal funds were sought for the deep water port, and Bethlehem Steel agreed to sell the government land for the port in the Burns Ditch area at $25 \%$ less than cost [8].

Indiana state administrators and politicians were solidly behind the establishment of a deep water port at Burns Ditch. They argued that the port was necessary to serve the steel mills planned to be built in the Burns Ditch area [9]. The proposed opening of the St. Lawrence Seaway in 1959 would bring ocean going import and export traffic to the South Shore of Lake Michigan, and promised to be a boon for Great Lakes industry.

Citizen action to prevent the destruction of the critically important habitat of the sand dunes in the Burns Ditch area began when residents of Gary, East Chicago, Hammond, and other communities in Northwest Indiana instituted a letter-writing campaign against the proposed harbor. The newly formed citizen action group, the Indiana Dunes Preservation Council, favored an 8,000 acre federal recreational park to serve local residents, and visitors from all over the world. They argued that the attendance strain at the Indiana Dunes State Park could be relieved by the creation of a federal park. They also argued that there was not a necessity for a new harbor at Burns Ditch. Rather, a deep water port could be built by enlarging the existing harbors at Indiana Harbor and Michigan City. These arguments were set forth in a pamphlet developed by Indiana Dunes Preservation council members, Edward M. Kratz and O.D. Frank [10] from Ogden Dunes, and Dr. R.M. Strong from Chicago [6]. The council was supported by many local, state, and national conservation organizations [11].

In 1952, it is reported that at a meeting of the citizen action group, the Chicago Conservation Council, President Dr. R.M. Strong asked the group how best to proceed to save the Indiana Dunes. Dorothy Buell, a resident of Ogden Dunes, proposed that perhaps the women could do it. Dr. Strong asked Mrs. Buell to spearhead the effort, and after a few days 
consideration, Mrs. Buell agreed to try [5]. Hence, the citizen action group, Save the Dunes council, was born in 1952 with its' mission to attempt to preserve the Indiana Dunes.

The initial meeting of the Save the Dunes council consisted of 21 women who met at the home of Mrs. Buell in Ogden Dunes. The council expanded to include men, eventually represented every state in the U.S. [5], and proved to be instrumental in the eventual establishment of the Indiana Dunes National Lakeshore.

\subsection{Ogden Dunes Residents Attempt to Limit Heavy Industry}

One mile to the west of Burns Ditch is Ogden Dunes, a residential community on Lake Michigan with a population in the 1950s of approximately 800 residents [12]. The residents of Ogden Dunes generated significant media coverage when they petitioned the Army Corps of Engineers to reject the Burns Ditch area as the site of the proposed deep-water port on the grounds that the port would harm the sand dunes, and adversely affect the property rights of the residents. A similar petition with more than 5,000 signatures was also presented to the Army Corps of Engineers objecting to the Burns Ditch area as the site of the proposed port. These petitions were unsuccessful, as Colonel Corey of the Army Engineers indicated that he could not take any action on the matter because the project was sanctioned by the state of Indiana $[13,14]$. However, the media coverage served to inform the public of the environmental consequences of the proposed port.

In 1957, the residents of Ogden Dunes made a bold move in their efforts to limit the advancement of heavy industry and preserve the residential character of the community and the Indiana sand dunes. The town plan commission adopted a zoning plan that would ban steel mills in its area. The town claimed zoning authority extending to within two miles of its borders. If upheld, that would give Ogden Dunes jurisdiction over a large part of the land purchased by the steel mills. Any building of heavy industry nearby would directly affect the quality of life of the residents of Ogden Dunes with potential air pollution, water pollution, and beach erosion. Even though Bethlehem Steel had not yet announced plans to build a mill [12], when the Board Chairman was asked what the plans were for the land, he replied "It's not for a bird sanctuary" [15]. Ogden Dunes also attempted to annex adjacent land that would bring the land under the zoning ordinances of Ogden Dunes, which prohibited heavy industry. Legal battles followed, and annexation was barred by a court order obtained by Inland Steel [16].

Ogden Dunes fought many unsuccessful lawsuits against Inland Steel, Midwest Steel, and the New York Central Railroad. Most of the local and state politicians favored heavy industry, and the establishment of a deep water port, and heavy industry had deep pockets for legal fees. Ogden Dunes also tried out of court negotiations, particularly on the issues of air and water pollution, and beach erosion. These negotiations were not successful, and Ogden Dunes conceded [17]. In 1960 the president of the Ogden Dunes board, Charles Graves, announced that Ogden Dunes would drop all lawsuits. They did not want to jeopardize future relations with the mills or risk political reprisals [18]. The picture below shows Charles Graves (right), the president of the Ogden Dunes board, shaking hands with Charles Halleck (left), the Indiana Representative that introduced the successful legislation for the establishment of the Burns Harbor Waterway. In the center is Mrs. Vohr, a resident of Ogden Dunes.

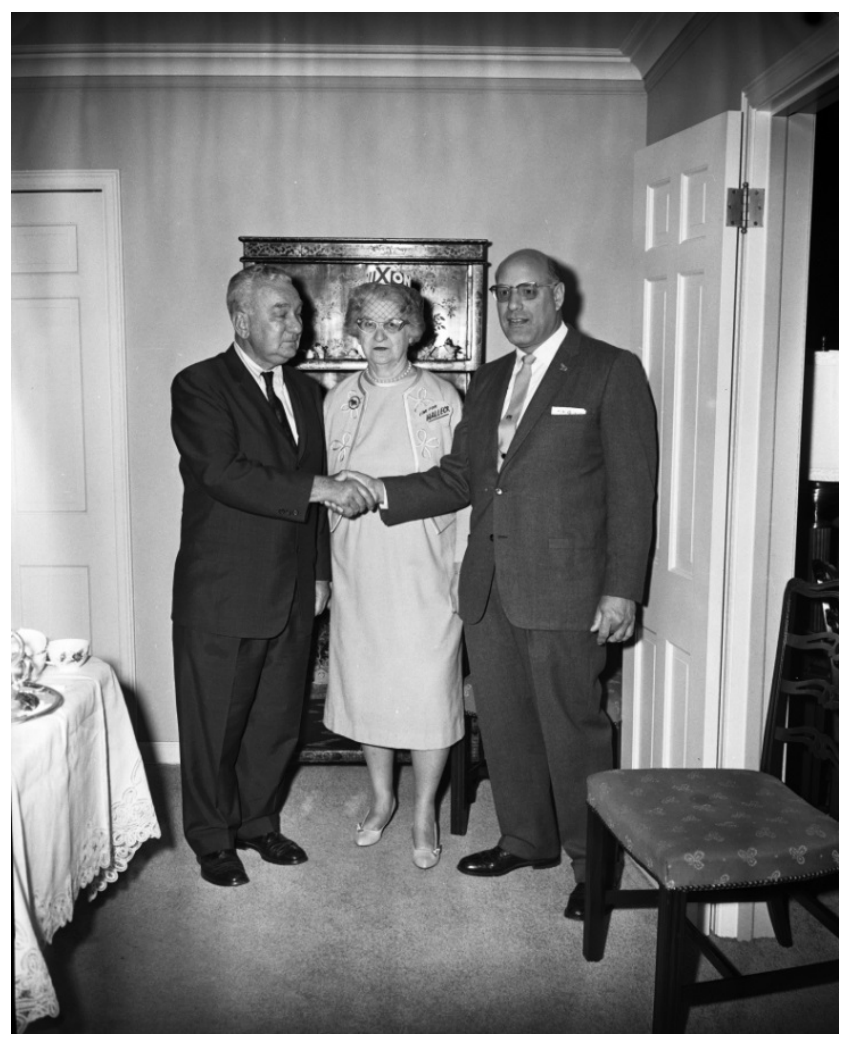

Photo credit: Stephen Mark.

Picture 2. Charles Halleck (left), Mrs. Vohr (center), Charles Graves (right)

\subsection{The Creation of the Town of Portage Zoned for Heavy Industry}

The state of Indiana passed a bill that would become law on July 1, 1959 that prohibited any area from incorporating as a town if it was within four miles of a first class city, and three miles of a second class city. At that time, the city of Gary had approximately 170,000 residents and was classified as a second class city. The steel mills used this opportunity to galvanize the residents of the area just east of Gary to incorporate as a town, and do it quickly before the bill became law, or forever lose the chance to do so. The residents of the area were in favor of heavy industry, and the steel mills saw this as the golden opportunity it was to create a town that would allow them to construct the factories that were being opposed by other communities [19]. 
A year and a half prior, plans were announced for the building of a $100+$ million dollar steel mill on the land immediately east of Burns Ditch by Midwest Steel. This caused property values to triple among the residents in the immediate area. Figures released by the Gary Chamber of Commerce estimated that 2,000 new factory workers would result in more than seven million dollars in retail sales per year. Portage was expected to increase its population from approximately 10,000 to 300,000 , and to be transformed into a heavily saturated urban area surpassing Gary in size [19].

With the impending state law set to take effect on July 1 , the industries mobilized quickly. Advisors donated by the industries mapped out each step needed for incorporation of the town of Portage, inclusive of 24 square miles. They made sure that the petitions were signed, the census survey was conducted, and the boundaries defined. The lure of jobs and wealth was irresistible. The city of Portage was created on June 29, 1959, two days before the law prohibiting the incorporation was to take effect [19].

Since Portage was incorporated too late in 1959 to assess taxes for 1959 or 1960, the town operated on gifts from local industries. Midwest, Bethlehem, and Inland Steel companies, along with the New York Central, the Chicago South Shore, and South Bend railroads contributed $\$ 90,000$ initially, and made significant subsequent contributions to the town of Portage. Furthermore, the industries contributed members of an industrial committee to act as advisors to help the town planning committee. The chairman of the advisory committee lived in Pennsylvania, and the vice chairman lived in Ohio. Both experienced planners flew to Portage whenever the town board requested [19]. The town of Portage never reached the population of 300,000 that was expected at the time of incorporation [19]. Its' current population is approximately 36,000 [20].

\section{Conclusion: Burns Harbor Waterway and the Indiana Dunes National Lakeshore}

After decades of struggle, Federal legislation provided for the establishment of both the Burns Harbor Waterway and the Indiana Dunes National Lakeshore. The Save the Dunes council, with Mrs. Dorothy Buell at the helm played the central role in the establishment of the Indiana Dunes National Lakeshore. The Save the Dunes council collected 100,000 signatures from citizens in Illinois, Indiana, and other states in support of preserving the dunes [21,22], and engaged the support of Senator Paul Douglas, who in 1958 introduced his first bill to the U.S. Congress for the creation of a national park to save remnants of the Indiana Dunes for future generations. However, the legislation got embroiled in hearings, and Congressional subcommittees. During this time, Douglas organized several trips for members of Congress to experience the Indiana Dunes first hand [5]. But while Congress took its time deliberating about establishing a national park, industry began to demolish the Indiana Dunes. In 1962, Bethlehem Steel announced plans to remove over two and a half million cubic yards of sand to be used as fill for Northwestern University's campus extension in Evanston, Illinois [23]. Bethlehem also announced that it would begin building a Burns Harbor plant. It then began clearing the land, and within a year much of the central dune area was demolished [24].

Senator Douglas persisted in introducing bills for the establishment of a national park until the Indiana National Lakeshore was established by Congress in 1966, thus providing federal protection to the remaining remnants of the sand dunes of Northwest Indiana [25]. In the same year, 1966, legislation approving the Burns Waterway Harbor deep water port was passed by the U.S. Congress. The Burns Harbor Waterway, built one mile east of Burns Ditch, opened in 1970 [26], allowing for shipping access to Lake Michigan. Today, the steel mills in the Burns Ditch area have changed owners, and currently employ thousands of employees. U.S. Steel now owns Midwest Steel, the mill immediately to the east of Burns Ditch [27]. The Burns Ditch waterway exists today for small boaters to utilize the entry to Lake Michigan. On one side is U.S. Steel, and on the other side is a small patch of the Indiana Dunes National Lakeshore. Burns Ditch's position, with a steel mill on one side and federally protected public land on the other represents the compromise between the supporters of heavy industry and the preservationists of natural land [28] that determined the composition of the south shore of Lake Michigan in Northwest Indiana.

The present article describes the citizen action strategies that helped preserve in perpetuity a large tract of land in Northwest Indiana over 50 years ago. These strategies continue to be relevant today (e.g., letter-writing campaigns, forming grassroots voluntary organizations, garnering support from politicians, and legal action). Advances in technology amplify connections with communities that benefit citizen action. Modern lobbying methods utilize email communications and the tremendous power of social media (e.g., Facebook, Twitter). Environment and governmental partners around the world can quickly mobilize. Land preservation issues that were once local and regional are now of national and worldwide importance. Millions of people are members of natural land and wildlife habitat preservation organizations such as The Nature Conservancy [3] and The World Wildlife Fund. Citizen action continues to be a cornerstone of the preservation of natural areas.

\section{REFERENCES}

[1] Buell, D. (1959). U.S. Congress, Senate, Committee on Interior and Insular Affairs, Indiana Dunes National Monument: Hearings on S.1001, $86^{\text {th }}$ Congress, $1^{\text {st }}$ sess., p. 156 . 
[2] Shepherd, S. (1959). Wealthy citizens, steel firms clash over Burns Ditch. Chicago Daily Tribune.

[3] Smith, S. \& Mark, S. (2009). The historical roots of The Nature Conservancy in the Northwest Indiana/Chicagoland region: From science to preservation. South Shore Journal (3) pp. 1-10.

[4] Smith, S. \& Mark, S. (2011). Marktown: Clayton Mark's Planned Worker Community in Northwest Indiana. South Shore Journal (4).

[5] Engel, J. R. (1983). Sacred sands: The struggle for community in the Indiana Dunes. Middletown, CT: Wesleyan University Press.

[6] Dunes State Park extension plea will go to legislature. (1952). Chicago Daily Tribune (1872-1963), ProQuest Historical Newspapers Chicago Tribune (1849-1986), p. S1.

[7] Nice, Constance. (1950). Voice of the people: Save the dunes. Chicago Daily Tribune (1872-1963), ProQuest Historical Newspapers Chicago Tribune (1849-1986), p. 16.

[8] Senator Capehart defends Indiana's port plan. (1959). Chicago Daily Tribune (1872-1963), ProQuest Historical Newspapers Chicago Tribune (1849-1986), p. 12.

[9] Scheele, H.Z. (1966). Charlie Halleck: A political biography. New York: Exposition Press.

[10] Smith, S. \& Mark, S. (2007). The cultural impact of a museum in a small community: The Hour Glass in Ogden Dunes. South Shore Journal (2) pp. 16-28.

[11] Fight to save beach dunes from industry: Letters hit plan for harbor. (1950). Chicago Daily Tribune (1872-1963), ProQuest Historical Newspapers Chicago Tribune (1849-1986), p. S1

[12] U.S. requests ruling to bar steel merger: Court schedules hearings Nov. 4. (1957). Chicago Daily Tribune (1872-1922), ProQuest Historical Newspapers Chicago Tribune (1849-1986), p. C9.

[13] Burns Ditch site opposed for a harbor. (1957). Chicago Daily Tribune (1872-1963), ProQuest Historical Newspapers Chicago Tribune (1849-1986), p. 3.

[14] Dig at plans for harbor in dunes area. (1957). Chicago Daily Tribune (1872-1963), ProQuest Historical Newspapers Chicago Tribune (1849-1986), p. S1.

[15] Ogden Dunes man speaks to save the dunes. (1957). Chicago Daily Tribune (1872-1963), ProQuest Historical Newspapers Chicago Tribune (1849-1986), p. A5.
[16] Ogden Dunes acts to block steel plant. (1959). Chicago Daily Tribune (1872-1963), ProQuest Historical Newspapers Chicago Tribune (1849-1986), p. A10.

[17] Ogden Dunes trades court war for talk: Midwest to start mill on schedule. (1959). Chicago Daily Tribune (1872-1963), ProQuest Historical Newspapers Chicago Tribune (1849-1986), p. S1.

[18] Ogden Dunes board bows to industry. (1960). Chicago Daily Tribune (1872-1963), ProQuest Historical Newspapers Chicago Tribune (1849-1986), p. S4.

[19] Kotulak, R. (1960). Courtship Tale: Blushing Portage and aggressive steel: New town planning for 300,000 residents. Chicago Daily Tribune (1872-1963), ProQuest Historical Newspapers Chicago Tribune (1849-1986), p. S1.

[20] U.S. Census Bureau (2010). http://quickfacts.census.gov/qfd/states/18/1861092.html.

[21] Indiana dunes national park bill planned. (1958). Chicago Daily Tribune (1872-1963), ProQuest Historical Newspapers Chicago Tribune (1849-1986), p. B16.

[22] Save the dunes petitions mount. (1958). Chicago Daily Tribune (1872-1963), ProQuest Historical Newspapers Chicago Tribune (1849-1986), p. 18.

[23] Sand removal from Dunes is hit at hearing: Northwestern's land fill at stake. (1962). Chicago Daily Tribune (1872-1963), ProQuest Historical Newspapers Chicago Tribune (1849-1986), p. 12.

[24] Hough. (1966). Heroine of Indiana Dunes. Chicago Sun Times.

[25] Warden, P. (1966). Dunes Park passed, sent to LBJ. Chicago Tribune (1963-current file). ProQuest Historical Newspapers Chicago Tribune (1849-1986), p. 1.

[26] World Port Source. (2012). http://www.worldportsource.com/USA_IN_Port_of_Indiana Burns_Harbor_127.php

[27] About U.S. Steel (2012). http://www.uss.com/corp/company/profile/about.asp

[28] Smith, S. \& Mark, S. (2006). Alice Gray, Dorothy Buell, and Naomi Svihla: Preservationists of Ogden Dunes. South Shore Journal (1) pp. 15-21. 